International Journal of Instruction

e-ISSN: 1308-1470 • www.e-iji.net
July $2019 \bullet$ Vol.12, No.3

p-ISSN: 1694-609X

pp. 389-404

Received: 03/10/2018

Revision: 05/04/2019

Accepted: 10/04/2019

OnlineFirst:09/05/2019

\title{
Android-Based Computer Assisted Instruction Development as a Learning Resource for Supporting Self-Regulated Learning
}

\section{Putriaji Hendikawati}

Department of Mathematics, Faculty of Mathematics \& Natural Sciences, Universitas Negeri Semarang, putriaji.mat@mail.unnes.ac.id

\section{Muhammad Zuhair Zahid}

Department of Mathematics, Faculty of Mathematics \& Natural Sciences, Universitas Negeri Semarang, zuhairzahid@mail.unnes.ac.id

\section{Riza Arifudin}

Department of Computer Science, Faculty of Mathematics \& Natural Sciences, Universitas Negeri Semarang, rizaarifudin@mail.unnes.ac.id

Computer Assisted Instruction (CAI) is one form of advances in information technology and computers that are proliferating today that can access anywhere and can be utilised as innovative learning resources. This research aims to develop Android-based Computer Assisted Instruction and evaluate its effectiveness. The Android-based CAI media were designed to improve students' ability both in Statistics and self-regulated learning. The development stages of this media referred to Borg \& Gall R \& D procedures that consist of 10 stages. Waterfall method was used to develop the Android-based CAI programming. Population in this research was the student of the first year in the mathematics education program. The sample for a small trial class and operational field testing was carried out using purposive sampling. The research used two non-test instruments: validation sheet and questionnaire to collect the data while descriptive analysis was used to analyse the data. At the end of the research, an application called Statistical Data Analysis (SDA) was produced, and it can be downloaded free on Google Play. Based on the results, it can be concluded that Android-based CAI is valid to be used as a learning resource, flexible, and supporting students' self-regulated learning.

Keywords: CAI, android, learning resource, self-regulated learning, instruction

Citation: Hendikawati, P., Zahid, M. Z., \& Arifudin, R. (2019). Android-Based Computer Assisted Instruction Development as a Learning Resource for Supporting Self-Regulated Learning. International Journal of Instruction, 12(3), 389-404. https://doi.org/10.29333/iji.2019.12324a 


\section{INTRODUCTION}

There are several efforts to improve the quality of education such as improving the quality of teaching, the design of teaching, learning resources, and learning media. Reynold \& Anderson (1992) classified media in ten categories, one of which is computer media. The current growth of information technology and computers requires the ability of educators to use it as one source of learning. Meanwhile, the use of computers in education has many advantages. Seels \& Richey (1994), states that using computers as learning media has many benefits such as its ability to be used randomly, according to students' wishes, and teachers also can also use it to prepare concepts using keywords, symbols, and graphs.

Furthermore, the theoretical study of computer-assisted learning was referred to various terms such as Computer-Assisted Instruction, Computer-Aided Instruction, ComputerAssisted Learning, Computer-Based Education, Computer-Based Instruction, ComputerEnriched Instruction, and Computer-Managed Instruction ("Computer Assisted Instruction," 2008). Computer-Assisted Instruction (CAI) is one alternative learning resource that can optimize the teaching and learning process. Some experts who have examined the integration of ICT into the education curriculum among others Hue (2013) and Zyad (2016).

Using CAI media in learning can facilitate the delivery of material because it was packaged in the form of computer and Android-based applications. CAI media can assist students to understand the material because CAI media is flexible and can be used according to the needs of each student based on student's abilities. The CAI media can accommodate students who lack to receive lessons and stimulate students to do the exercises. This because of the availability of animated graphics, colours, and music that can make the concept more realistic.

Applications of ICT can also be used to help and facilitate teachers in preparing lessons. Nawi (2015) finds that the use of applications on mobile phones can help teachers prepare the lesson and gives contentment to the teachers in enhancing their knowledge in teaching. However, the study revealed that the users' age factor is still important due to its effects on the frequency of mobile phone usage. Besides, the study found that the use of mobile technology among teachers is appropriate and supporting the teaching activities.

According to various sources, CAI (and the variants of the term) can have a positive impact on learning, especially concerning about learning outcomes achieved by learners. Some researchers use experimental study to compare the effectiveness of CAI with conventional instruction (Ragasa, 2008; Aktaruzzaman \& Muhammad, 2011; Mahmood \& Mirza, 2012) while others tend to find the impacts of CAI on the learning achievements (see Qayumi et al., 2004) and its effects in learning for learners with special needs (Rice et al., 2015). At the college level, mathematics learning using CAI shows different effects; some studies show less significant impacts of CAI on the achievement of learning outcomes (see Delafuante et al., 1998; Spradlin \& Ackerman, 2010), others find that CAI has no significant impact on learning outcomes but affects 
the establishment of a positive learning environment (Schumacker, 1995), and the others find that CAI has positive impact in learning mathematics (Bennet, 2012; Ragasa, 2008).

Erdogan (2015) compare the effects of computer-assisted project-based instruction on learners' achievement in a science and technology course, in a computer course and portfolio development. At the end of the study, the findings revealed that science, technology, and portfolio assessment scores of the experimental group were significantly higher than that of the control group. This result indicates that the learning gains are higher when the instruction is provided by computer-assisted project-based instruction than by the traditional method. In the other research, Ziden (2013) studied the effectiveness of using multimedia virtual simulation in Islamic Studies in Malaysia. The result showed that virtual simulation allows students to interact with a virtual environment that almost similar to the real environment in Mecca. The finding of this study shows that the use of virtual simulation helps students to increase their achievement in a topic of pilgrimage.

Android is a software platform and operating system based on the Linux kernel. For the first time, this platform was developed by Android Inc. which was founded by Andy Rubin. Initially, the company acquired an operating system for digital cameras, before realising that the market share of digital cameras is not too significant, and eventually shifted to develop the operating system for smartphones. Currently, Android is developed by Google and Open Handset Alliance with Android Open Source Project (AOSP) (Kasman, 2013; Bhardwaj et al., 2013; Gilski \& Stefanski, 2015; Narmatha et al., 2016) as the best-selling operating system in the world for the smartphone category. Over 300 million devices use this OS, and 850 thousand new devices are activated every day (Bhardwaj et al., 2013). Android market share worldwide now reaches $73.05 \%$, compared to its closest competitor, iOS, that only get $19.99 \%$ of market share ("Mobile operation," 2017). In July 2017, Android also gained the highest market share in Indonesia of $83.99 \%$, while iOS only got 3.09\% ("Market share held," 2017).

Currently, almost all students have mobile phones, and most of them are using Androidbased smartphones. Unfortunately, smartphones are only used as a media of communication and entertainment. Only some students use it for educational purposes, especially in learning mathematics, even though Android smartphones on school-age can be used to deliver the subject matter. By using smartphones, students can learn actively without direct guidance from teachers. This research developed interactive multimedia CAI that was designed for web-based learning and accessed by an Android app. Statistics selected as the materials in CAI development because of its extensive implementation in real life. The use of Android-based CAI media was expected to deliver the concepts of subject materials more optimally because CAI media can contain text, images, and audiovisual which are expected to be easy to understand. In addition, it is also expected that the Android-based CAI can be used by students to learn according to their academic anytime and anywhere.

Moreover, Abdelraheem (2018) investigated the impact of using Mobile Social Network Applications (MSNAs) on students' social life (social relations, family relations, and 
social awareness). The results indicated that the overall impact of MSNAs was at a moderate degree $(M=3.23)$. Social relation, family relation and awareness of current issues were at the same degree (Means $=3.41,3.23,3.61$ respectively). The study concluded that the use of (MSNAs) got moderate degrees in the effect to the students' social life. Furthermore, the study recommended the use of a large sample and more variables' scale of social life.

Other research conduct by Arista (2018) produced a virtual physics laboratory application called ViPhyLab using the Android smartphone as the basis. The study gives results that ViPhyLab is usable to be operated for learning both inside and outside the school and the ViPhyLab is quite viable as learning media with very good quality. These results indicate that learning media integrated with Android smartphone can be used anywhere at all social levels.

Self-regulated learning means that students learn without any help from others to receive their learning goals. It involves a conscious effort of learners to manage complex learning activities. Moreover, self-regulated learning can train students to be more responsible and independent of others. It also fosters their self-confidence and makes them learn new subjects quickly. The students in self-regulated learning tend to have the confidence to face challenging tasks, practice what they learn, and achieve depth understanding of the subject matter. Besides, they can also control their learning environment and manage their actions to achieve their learning goals (Schunk et al., 2012; Kauffman, 2004; Suhendri, 2012; Handoko, 2013; Palinscar \& Brown, 1984). Several studies have attempted to describe how student self-regulated learning effects in distance learning (Maldonado-Mahauad et al., 2018), flipped course (Sun et al., 2018), online learning (Huh \& Reigeluth, 2018; Broadbent, 2017), and blended learning (Broadbent, 2017).

Considering the importance of understanding the course material and students' selfregulated learning in universities; it is essential to apply appropriate learning models and resources to make students improve academic ability and self-regulated skill. Therefore, the purpose of this research is to design and develop Android-based CAI products as learning resources that can encourage students to study independently with their level of understanding of statistical concepts.

\section{METHOD}

\section{Design of the Research}

This study uses research and development (R \& D) model developed by Borg \& Gall. The purpose of this research is to develop CAI in the form Android application that can and test its effectiveness. The stages of development, which are referred to as Borg \& Gall, contain ten stages: (1) information collecting, (2) planning, (3) developing a preliminary form of product, (4) initial field testing, (5) first product revision, (6) field testing, (7) second product revision, (8) operational field testing, (9) final product revision, and (10) dissemination and implementation (See Gall et al., 1996). The final product in this research is an application that tested successfully in expert validation and practicality test. 


\section{Participants and Sampling Technique}

This research was conducted in the Department of Mathematics at one university in Semarang, Central Java, Indonesia. Population in this research was all students of the first year in the mathematics education program while the sample was a class selected from 5 classes. A class was carried out as the sample for small-class trials while operational field-testing used purposive sampling to get the subjects. Students which has been chosen as a sample for the small class trial and operational field test was the second-year students who have received a statistical lecture.

\section{Procedures of the Implementation}

The media development in this research has reached the ninth stage (final product revision) from ten stages Brog \& Gall model. The stages of media development that have been carried out are described in the description as follow.

In the information collecting step, the literature study, observation, and collecting the information were conducted from subject research. Then in the planning stages, materials contained in the CAI media was formulated and prepared as well as the research instrument. In the third stage, the developing stage, a preliminary form of the CAI media was developed by using various software. Furthermore, in the fifth stage, the initial field test, the media was tested by two experts regarding validity. The validity test is about the application content and media aspect. In this stage, the experts had given some suggestions for the CAI media.

Consequently, the media was revised to adjust the experts' suggestions. The next stage was the field-testing stage which contained a limited trial of the CAI in a small class to obtain opinions and user ratings on media assessment indicators. In this stage, the ratings and suggestions of users in small classes were used for the next revision which produces the second-revision product. The result of the second revision then used in the operational field test which contains the collection of users' perceptions related to the effectiveness of CAI media in learning and its effects on increasing self-regulated learning. After the stage of an operational field test, the research was finished since the final product was developed.

\section{Data Collection Instruments}

Data collection in this study was conducted using two non-test instruments: a validation sheet of expert assessment and a user questionnaire. A validation sheet was used to obtain expert judgment about content and media development while the questionnaire was used to measure the opinions and perceptions of students about the benefits of the media and the influence of CAI media to students' self-regulated in learning. The questionnaire contains several indicators about the perception of the media, which uses the Likert scale for each item in score 1-5. Additionally, the validity of the questionnaire had been tested by an expert before it was used. 


\section{The Instrument of Validity}

The first step that should pass by the CAI media before it can be used is the validity test. The CAI media's validity assessed was content validity and development validity. Two lecturers of Statistics have been chosen as the experts in the content validity test which was related to the assessment of the material in the CAI media, whether it adjusts the competency standards or not. There were three aspects of the contents of CAI media which contains 16 statements that have been validated: the concept of the material, the appearance of the media, and the ability of media to foster self-regulated learning.

Meanwhile, the validators of development validity were two lecturers who have particular expertise in media development. The development validity that consists of 15 items contains two aspects: the display of the media and the technical quality of the media. The result of those two validations was used for revision and improvement of developed media.

\section{The Instrument of User Perception}

The user perceptions of the CAI media were carried out to know the user perceptions about the media. Respondents in this stage were students in a small-trial class who have attended Statistics lectures before. Two questionnaires were used to get perception from the user about the media. The first questionnaire assessed user perceptions of linguistic, implementation, visual display, and software engineering aspect, while the questionnaire assessed the elements of media that support learning such as media effectiveness, learning motivation, and learning activities. The students were asked to use the CAI media, which had been revised after the validity test, and then fill the questionnaires.

\section{Self-Regulated Instrument}

The self-regulated instrument was carried out to get information from the user about the effects of the use of CAI media in supporting students self-regulated. This instrument was given to all students in the operational field test while the aspects that were assessed in this questionnaire consist of 15 statement.

\section{Data Analysis}

Data that were obtained from the validity test were tested to determine whether experts have the same consideration about the content validity and media development or not. The results of the validation are explained in the preliminary field-testing subsection in the finding and discussion section. The data of validation and user perception, which were related to media development and user perception, were tested using descriptive statistical analysis and used the classification made by Widoyoko (2013). Widoyoko

(2013) has made a classification with a comparison to the ideal mean score $\left(\mathrm{X}_{\mathrm{i}}\right)$ and the ideal standard deviation score $\left(\mathrm{SB}_{\mathrm{i}}\right)$. The classification is in five categories as shown in Table 2. 
Table 2

Classification Category

\begin{tabular}{lll}
\hline Score Range & Average Score & Category \\
\hline $\bar{X}>X_{\mathrm{i}}+1.8 S B_{\mathrm{i}}$ & $\overline{\mathrm{X}}>4.2$ & Very Good \\
$X_{\mathrm{i}}+0.6 S B_{\mathrm{i}}<\bar{X} \leq X_{\mathrm{i}}+1.8 S B_{\mathrm{i}}$ & $3.4<\overline{\mathrm{X}} \leq 4.2$ & Good \\
$X_{\mathrm{i}}-0.6 S B_{\mathrm{i}}<\bar{X} \leq X_{\mathrm{i}}+0.6 S B_{\mathrm{i}}$ & $2.6<\overline{\mathrm{X}} \leq 3.4$ & Good Enough / Fair \\
$X_{\mathrm{i}}-1.8 S B_{\mathrm{i}}<\bar{X} \leq X_{\mathrm{i}}-0.6 S B_{\mathrm{i}}$ & $1.8<\overline{\mathrm{X}} \leq 2.6$ & Poor \\
$\bar{X} \leq X_{\mathrm{i}}-1.8 S B_{\mathrm{i}}$ & $\overline{\mathrm{X}} \leq 1.8$ & Very Poor \\
\hline
\end{tabular}

The self-regulated questionnaire was using the same classification as well as data of validation and user perception with a different scale which was from 1 to 4 .

\section{FINDINGS AND DISCUSSION}

The detailed procedures for each stage of media development are described as follows.

\section{Information collecting}

This stage contains literature studies, observation, and problem identification which eventually led the researchers to choose Android as the platform of CAI media as well as statistics as the primary material. The process of learning statistics includes studying the concepts and applying the concepts to solve problems which led the researchers to conclude that the media should have two features: the ability to display theory of statistics and the ability to analyse the data. The menu of the theory of statistics is used by the students to learn concepts while the menu of data analysis allows students to apply the concepts to solve problems.

\section{Planning}

After collecting the information, this study chose the appropriate statistics materials that should be displayed in the media as well as a case study, teaching materials, assessment instrument, and self-regulated instrument. The researchers then determined the hosts for offline and online installation of media. The Personal Home Page Hypertext Preprocessor (or simply PHP) with Code Igniter Framework was used as the main developing framework while App Inventor was utilised to develop the Android app. PHP was chosen because its code has been widely used and can be used on web servers on almost all operating systems and platforms as well as free of charge (Gawas et al., 2015).

Meanwhile, Code Igniter is an application development framework for programmers who create websites using PHP. Code Igniter was used as a PHP framework because it allows developing projects faster than writing code from scratch by providing a rich collection of libraries, simple interfaces, and logical structures for easy access to libraries. The Code Igniter allowed programmers to focus on projects without having to 
think too hard about the amount of code required (Jaiswal \& Yagyasen, 2015). Furthermore, the App Inventor was chosen due to its unique ability to handle drag, drop and arrange various interfaces, components and behaviour logic to create full functioning mobile apps (Hsu et al., 2012; Wolber, 2011).

\section{Development of a preliminary form of the product}

The development of the CAI media was started by preparing the supporting components, development guidelines, and evaluation tools. The CAI media which named Statistics Data Analysis (SDA) was developed using the Waterfall Method: analysis, design, writing, testing, application, and maintenance. The CAI media had been considered to accommodate the concepts of statistics and the practice of analysing the data. After that, the CAI media then designed more technically using case diagram and map-interface diagram. Moreover, in this substage, the researchers then divided users into two categories with their respective authorities: administrators and users and also design the primary display (main page and the homepage) of the CAI media. Anyone can access the concepts of statistics contained in the CAI media, but if users want to use the menu of Data Analysis, they need to sign in first.

The following substage is the implementation of the design into the code by translating the design into a form that can be understood by the machine using PHP, Code Igniter framework, and MySQL. After that, the result of the implementation was tested concerning the logic of the software to ensure that all program code has worked. Black box technique was used to find whether the designed CAI media has errors or not. Eventually, after testing the software, the final substage is implementation and maintenance the CAI media. The detailed development steps are in Hendikawati et al. (2018) while the results of development are in Figure 1. 

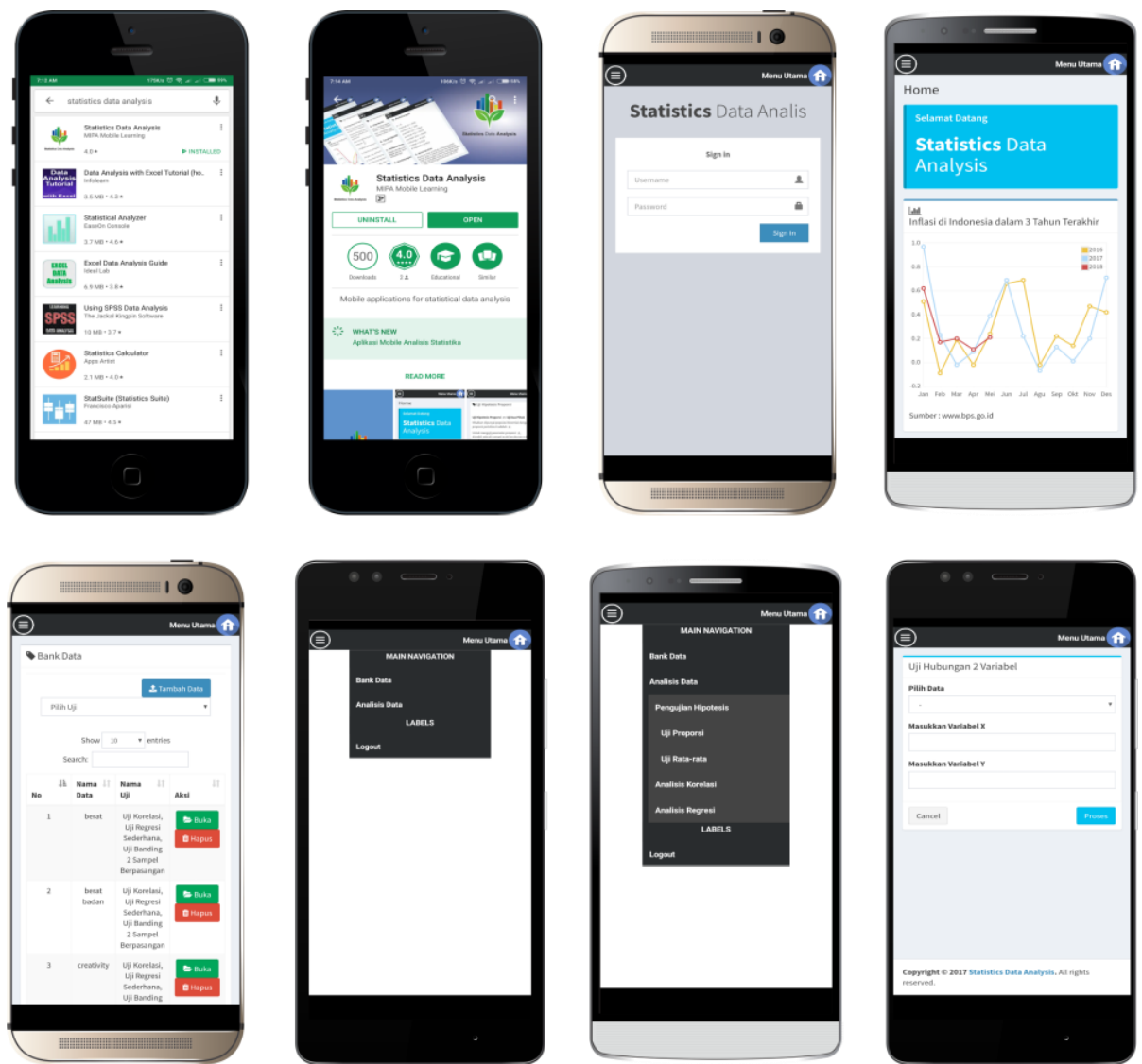

Figure 1

Design of CAI media

Preliminary field test

There was a preliminary field test following the preliminary development. In this stage, the validity of content and development was observed by the experts. The content validity was about the suitability of the media to competency standard of the statistics course while the validity of media development was about several aspects such as statistics material indicators, media display, and the ability of media to foster selfregulated learning. The results of the experts' validation are in Table 2. 
Table 2

Expert Validation Result

\begin{tabular}{lllll}
\hline Aspect & $\begin{array}{l}\text { Scores } \\
\text { Expert 1 }\end{array}$ & Expert 2 & Mean Score & Category \\
& \multicolumn{2}{l}{} & \\
\hline \multicolumn{2}{l}{ Media Content (Statistics Material) } & & & \\
\hline The concept of the material & 4.2 & 4.2 & 4.2 & Good \\
Appearance & 4.4 & 4.2 & 4.3 & Very Good \\
Self-regulated & 4 & 5 & 4.5 & Very Good \\
\hline Media Development & & & & \\
\hline The appearance & 4.25 & 4.25 & 4.25 & Very Good \\
Technical quality & 2.7 & 4 & 3.35 & Good Enough \\
\hline
\end{tabular}

Table 2 gives information about the result of the validity test. Overall, all of the aspects in both media content and media development got a good rating. The ability of media to foster self-regulated learning got the highest judgement (mean score: 4.5) while the aspect of technical quality was the weakest aspect since it only got 3.35 for its mean score and got predicate of "good enough". Other aspects vary in interval 4.2 to 4.3.

Furthermore, the experts still give some recommendations such as that the media contained some disturbances and there were some shortcomings in the system that must be revised. However, both experts considered that the media had passed both validities of media content and media development. Additionally, there were several suggestions given by the experts to improve the display and the replenishment of some submenus.

\section{Main product revision}

The suggestions given by the experts in the preliminary field test were: (1) the display needed to be made more interesting, (2) some images display still looked stiff and could not be shifted, (3) the register menu for new users was working imperfectly, (4) it needed more additional exercise and case study, (5) in the menu of case study, there were several data that could not be clearly readable, and (6) the output display that appeared in the application after the data analysis process needed to display appropriately so it can be read and understand by the user. The stage of main product revision used the suggestions as for the basis of the revision process.

\section{Main field test}

The main field test contained a trial for the CAI media that had been revised in a small Statistics class. The class consisted of 22 students, sixteen of whom were female and six of whom were male. The trial was conducted in six meetings consisted of: (1) technical information about the media and how to use it, (2) activities in lectures which were using CAI media, and (3) filling out the questionnaires. The questionnaires contained the indicators of the students' experiences of the media.

The first questionnaire related to indicators of the technical components of the media: (1) language aspects, (2) implementation aspects, (3) display aspects, and (4) software engineering aspects. The students in the main field test gave $82.62 \%, 84.55 \%, 86.88 \%$, and $85.27 \%$ for the aspect of language, implementation, display, and software 
engineering respectively. The second questionnaire was related to elements of media usage: (1) media effectiveness, (2) learning motivation, and (3) learning activities. The three indicators also obtained high ratings from users with a value of $83.75 \%, 78.64 \%$, and $82.73 \%$ respectively. These showed that both in the technical aspect and media development, the CAI media had satisfied the standard of application program technique expected by the users.

Regarding the feasibility of the media more than half of 22 respondents argued that the media has met the criteria of suitable and could be used with a slight revision. The others argued that CAI media were excellent and could be used without change. However, there was one student who thought that the media could be used with some revisions. The students' perceptions of CAI media can be seen in table 3 .

Table 3

User Perception of Android-Based CAI Media

\begin{tabular}{lll}
\hline \multicolumn{1}{c}{ Category } & Score & Respondent \\
\hline The CAI media based on Android is very poor cannot be used & $15-26$ & $0(0 \%)$ \\
The CAI media based on Android is poor can be used with & $27-38$ & $0(0 \%)$ \\
$\begin{array}{l}\text { many revisions } \\
\begin{array}{l}\text { The CAI media based on Android is good enough to be used } \\
\text { with some revisions }\end{array}\end{array}$ & $39-50$ & $1(4,6 \%)$ \\
$\begin{array}{l}\text { The CAI media based on Android is good can be used with a } \\
\text { little revision }\end{array}$ & $51-62$ & $12(54,5 \%)$ \\
$\begin{array}{l}\text { The CAI media based on Android is very good can be used } \\
\text { without revision }\end{array}$ & $63-75$ & $9(40,9 \%)$ \\
\hline
\end{tabular}

\section{Second product revision}

The stage of second product revision used the suggestions from the students in the main field test as the basis of the revision process. There were some suggestions given by the students: (1) the responsiveness of the application must be increased, (2) the users might need more detailed information about how to use the app, (3) it is necessary to make some improvement about the appearance of narrative contents, and (4) the statistics materials, problems, and features for exercises should be more complicated.

\section{Operational field test}

The next stage after the second product revision was the operational field test which conducted in a statistics class consisted of 25 students. The test was in ten lecture activities using the CAI media, and in the last meeting, the students filled the selfregulated questionnaire. The students' perceptions of CAI media about self-regulated learning are in Table 4. 
Table 4

User Respond of Android-Based CAI media for Self-Regulated Learning

\begin{tabular}{llll}
\hline Score Range & Average Score & Category & Respondent \\
\hline $\bar{X} \geq X_{\mathrm{i}}+1.8 S B_{\mathrm{i}}$ & $\overline{\mathrm{X}} \geq 3.4$ & Very Good & $3(12 \%)$ \\
$X_{\mathrm{i}}+0.6 S B_{\mathrm{i}} \leq \bar{X}<X_{\mathrm{i}}+1.85 B_{\mathrm{i}}$ & $2.8 \leq \overline{\mathrm{X}}<3.4$ & Good & $19(76 \%)$ \\
$X_{\mathrm{i}}-1.8 S B_{\mathrm{i}} \leq \bar{X}<X_{\mathrm{i}}+0.6 S B_{\mathrm{i}}$ & $1.6 \leq \overline{\mathrm{X}}<2.8$ & Poor & $3(12 \%)$ \\
$\bar{X}<X_{\mathrm{i}}-1.8 S B_{\mathrm{i}}$ & $\overline{\mathrm{X}}<1.6$ & Very Poor & $0(0 \%)$ \\
\hline
\end{tabular}

Most of the students $(76 \%)$ said that the CAI media had reached the predicate of "good" while $12 \%$ of them considered that the media had reached the predicate of "very good". Additionally, there were $12 \%$ of students thought that the media had reached only the predicate of "poor".

At the first meeting, students were still confused and had difficulties in operating the media. However, with the frequent use of applications in lectures and completion of tasks, students became more proficient using the media and could feel that the media is beneficial. Students had felt that the media could make statistics learning more exciting and fun for several reasons such as: (1) the CAI media can solve statistics problems quickly, (2) the CAI media is easy to operate, (3) the CAI media has attractive appearance compared with other statistic software, (4) the CAI media can be used for data processing and generate fast statistical calculations with accurate results, and the CAI media is designed for mobile and make it simple to be used anytime.

Furthermore, base on the self-regulated questionnaire results, many students have felt that the use of Android-based CAI media application could improve students selfregulated learning since the app can be used anywhere and anytime. The contents and explanations given in the app were easy to understand and made the students could access the application individually. However, some students did not feel accustomed to use the CAI media and make them think that the media was difficult to use.

\section{Final product revision}

After the operational field test, then the media was revised for the final amendment for the final product. Finally, this final product has been distributed widely on Google Play Store under the name "Statistics Data Analysis" and can be downloaded free.

\section{CONCLUSION}

The results of this research show that the development of Android-based CAI media can be used as a learning resource that supports self-regulated learning. The developed media was valid based on expert considerations and user opinions. Meanwhile, the Android-based CAI media satisfied the criteria of material contents and media development. The media also can be stated as valid to be used as a learning resource, flexible to be used in learning and supporting student self-regulated learning. The media 
also has been tested in a small group with good results. In conclusion, this research has been successfully developed Android-based CAI media as learning resources that can encourage students to study independently in a statistics course.

\section{REFERENCES}

Abdelraheem, A Y, \& Ahmed, A M. (2018). The Impact of Using Mobile Social Network Application on Student's Social-Life. International Journal of Instruction, 11(2), 1-14.

Aktaruzzaman, M., \& Muhammad, K. (2011). A comparison of traditional method and computer-aided instruction on students achievement in educational research. Academic Research International, 1(3), 246.

Arista, F S, \& Kuswanto, H. (2018). Virtual Physics Laboratory Application Based on The Android Smartphone to Improve Learning Independence and Conceptual Understanding. 2018. International Journal of Instruction, 11(1), 1-16.

Bennet, S. M. (2012). The Effect of Computer Assisted Instruction on Rural Algebra Students. Northern Michigan Unversity July 29, 2012.

Bhardwaj, S., Chauhan, P., \& Sharma, R. Sharma, P. (2013). Android operating systems. International Journal of Engineering Technology and management research, 1(1), 147-150

Broadbent, J. (2017). Comparing online and blended learner's self-regulated learning strategies and academic performance. The Internet and Higher Education, 33, 24-32

Computer Assisted Instruction (CAI). (2008). http://wikieducator.org/Computer_Assisted_Instruction_(CAI)

Delafuente, J. C., Araujo, O. E., \& Legg, S. M. (1998). Traditional lecture format compared to computer-assisted instruction in pharmacy calculations. American Journal of Pharmaceutical Education, 62(1), 62.

Erdogan, Y, \& Dede, D. (2015). Computer Assisted Project-Based Instruction: The Effects on Science Achievement, Computer Achievement, and Portfolio Assessment. International Journal of Instruction, 8(2), 177-188.

Gall, M. D., Borg, W. R., \& Gall, J. P. (1996). Educational research: An introduction. Longman Publishing.

Gawas, D., Ramakrishnan, J., Joshi, D., \& Khochare, N. (2015). Centralized E-Book Storage using Cloud. International Journal of Current Engineering and Technology, 5(2), 840-842.

Gilski, P., \& Stefanski, J. (2015). Android OS: A Review. Journal Technology, Education, Management, Informatics, TEM Journal, 4(1), 116-120.

Handoko, H. (2013, October). Pembentukan Kemampuan Berpikir Kreatif Pada Pembelajaran Matematika Model SAVI Berbasis Discovery Strategy di Laboratorium 
Teezania. In Prosiding Seminar Nasional Matematika VII UNNES (Vol. 26, pp. 287192).

Hendikawati, P., Arifudin, R., \& Zahid, M. Z. (2018, March). Development of computer-assisted instruction application for statistical data analysis android platform as learning resource. Journal of Physics: Conference Series (Vol. 983, No. 1, p. 012057). IOP Publishing.

Hsu, Y. C., Rice, K., \& Dawley, L. (2012). Empowering educators with Google's Android App Inventor: An online workshop in mobile app design. British Journal of Educational Technology, 43(1).

Hue, L T, \& Jabil, H A. (2013). Attitudes Toward ICT Integration into Curriculum and Usage among University Lecturers in Vietnam. International Journal of Instruction, 6(2), 53-66.

Huh, Y., \& Reigeluth, C. M. (2018). Online K-12 teachers' perceptions and practices of supporting self-regulated learning. Journal of Educational Computing Research, 55(8), 1129-1153.

Jaiswal, A. K., \& Yagyasen, D. (2015). Automatically Inventory Update Using Code Igniter Framework With Cronjob. Global Journal of Multidisciplinary Studies, 4(6), 187-192

Kasman, A. D. (2013). Kolaborasi Dahsyat Android dengan PHP dan $M y S Q L$. Yogyakarta: Lokomedia.

Kauffman, D. F. (2004). Self-regulated learning in web-based environments: Instructional tools designed to facilitate cognitive strategy use, metacognitive processing, and motivational beliefs. Journal of educational computing research, 30(12), 139-161.

Mahmood, M. K., \& Mirza, M. S. (2012). Effectiveness of Computer-Assisted Instruction in Urdu Language for Secondary School Students' Achievement in Science. Language in India, 12(2).

Maldonado-Mahauad, J., Pérez-Sanagustín, M., Kizilcec, R. F., Morales, N., \& MunozGama, J. (2018). Mining theory-based patterns from Big data: Identifying self-regulated learning strategies in Massive Open Online Courses. Computers in Human Behavior, 80, 179-196.

Market share held by mobile operating systems in Indonesia from January 2012 to July 2017. (2017). https://www.statista.com/statistics/262205/market-share-held-by-mobileoperating-systems-in-indonesia/

Mobile operating system market share worldwide - October 2017. (2017) http://gs.statcounter.com/os-market-share/mobile/worldwide 
Narmatha, S. \& Venkata KrishnaKumar, S. (2016). Study on Android Operating System And Its Versions, International Journal of Scientific Engineering and Applied Science (IJSEAS), 2(2), 439-444

Nawi, A, Hamzah, M I, Ren, C C, Tamuri, A H. (2015). Adoption of Mobile Technology for Teaching Preparation in Improving Teaching Quality of Teachers. International Journal of Instruction, 8(2), 113-124.

Qayumi, A. K., Kurihara, Y., Imai, M., Pachev, G., Seo, H., Hoshino, Y., ... \& Lara-Guerra, H. (2004). Comparison of computer-assisted instruction (CAI) versus traditional textbook methods for training in abdominal examination (Japanese experience). Medical education, 38(10), 1080-1088.

Palinscar, A. S., \& Brown, A. L. (1984). Reciprocal teaching of comprehensionfostering and comprehension-monitoring activities. Cognition and instruction, 1(2), 117-175.

Ragasa, C. Y. (2008). A comparison of computer-assisted instruction and the traditional method of teaching basic statistics. Journal of Statistics Education, 16(1), 62-78.

Reynolds, A., \& Anderson, R. H. (Eds.). (1992). Selecting and developing media for instruction. John Wiley \& Sons Incorporated.

Rice, L. M., Wall, C. A., Fogel, A., \& Shic, F. (2015). Computer-assisted face processing instruction improves emotion recognition, mentalizing, and social skills in students with ASD. Journal of autism and developmental disorders, 45(7), 2176-2186.

Schumacker, R. E. (1995). Math attitudes and achievement of Algebra I students: a comparative study of computer-assisted and traditional lecture methods of instruction. Computers in the Schools, 11(4), 27-33.

Sell, B., \& Richey, R. C. (1994). Instructional Technology: The Definition and Domain of The Field (AECT). Washington DC.

Schunk, D. H., Meece, J. R., \& Pintrich, P. R. (2012). Motivation in education: Theory, research, and applications. Pearson Higher Ed.

Spradlin, K., \& Ackerman, B. (2010). The Effectiveness of Computer-Assisted Instruction in Developmental Mathematics. Journal of Developmental Education, 34(2), 12.

Suhendri, H. (2011). Pengaruh kecerdasan matematis-logis dan kemandirian belajar terhadap hasil belajar matematika. Jurnal Formatif, 1(1), 29-39.

Sun, Z., Xie, K., \& Anderman, L. H. (2018). The role of self-regulated learning in students' success in flipped undergraduate math courses. The Internet and Higher Education, 36, 41-53.

Widiyoko, S. E. P. (2013). Evaluasi Program Pembelajaran: Panduan Praktis Bagi Pendidik dan Calon Pendidik. Pustaka Pelajar. Yogyakarta. 
Wolber, D. (2011, March). App Inventor and real-world motivation. In Proceedings of the 42nd ACM technical symposium on Computer science education, 601-606.

Ziden, A A. (2013). The Effectiveness of Web-Based Multimedia Application Simulation in teaching and Learning. International Journal of Instruction, 6(2), 211222.

Zyad, H. (2016). Integrating Computers in the Classroom: Barriers and Teachers' Attitudes. International Journal of Instruction, 9(1), 65-78. 